\title{
Physics Learning with Metacognitive Approach through Problem Based Learning (PBL) and Reciprocal Learning (RL) model Viewed from Students' Critical Thinking Skill
}

\author{
Sulasih $^{1}$, Sarwanto $^{2}$, Suparmi $^{3}$ \\ ${ }^{1,2,3}$ Postgraduate Program of Science Education, Faculty of Teacher Training and Education, \\ Sebelas Maret University, Surakarta, Indonesia \\ Corresponding email: $\underline{\text { salwa_777@yahoo.co.id }}$
}

\begin{abstract}
Teachers have not been optimal in strengthening the student's cognitive awareness in learning physics. This study aims to determine the effect of learning with a metacognitive approach through Problem Based Learning (PBL) and Reciprocal Learning (RL) model among students who have high critical thinking ability and low critical thinking ability. This research is an experimental study with the $2 \times 2 \times 2$ factorial design. Object research is students of grade 11 science class in a high school in Central Java. The sample was obtained by cluster random sampling technique obtained by one class as an experimental and another class as a control. Data collection techniques use test techniques for their cognitive learning outcomes as well as their critical thinking skills and questionnaire and observation techniques for their attitude and skill learning outcomes. Analysis of the data using ANOVA 2 ways. The results show: (1) there are differences in learning outcomes between students who were given Physics learning model of PBL with reciprocal learning model. (2) There are differences in learning outcomes between students who have high critical thinking skills and low critical thinking skills. (3) There is no interaction between physics learning of PBL model and Physics learning of reciprocal learning model with students' critical thinking ability.
\end{abstract}

Keywords: critical thinking ability; learning achievement; PBL; RL

DOI: $10.20961 /$ ijpte.v\%vi\%i.19896 


\section{INTRODUCTION}

The current learning tends to be mastered by the teacher so that the students are less active, the teacher gives the students request, and the teacher explains the students listen. The weak interaction between student and teachers so that learning has not been able to cultivate a sense of curiosity, critical power, creativity, innovation and not able to actualize the potential of students. It requires teachers to be creative in applying and developing appropriate learning models so that learning becomes more meaningful. Problems in the learning activities of Physics class XI is students do not like and do not know the nature of physics, it makes students feel difficulty in understanding the physics itself.

Students have difficulties to ask the teacher when the learning is taking place, this is the obstacle to the student's learning. They have not been able to analyze the material being studied. It also makes it difficult for teachers to know how far the material can be understood by the students after the teacher explains. Students lack enthusiasm in learning which is likely caused by unattractive, saturating and monotonous learning activities. According to this problem, then they required a model that can increase awareness the importance of learning in order to achieve satisfactory learning achievement. Students will try to achieve self-actualization well because the learning experience is also interesting and demanding active students. One model that can be used to overcome these problems with problembased learning model (PBL) and Reciprocal learning involving students active in gaining knowledge.

One of the main educational goals is to teach about the nature of science that students must engage in inquiry and produce products in the form of facts, concepts, principles, theories, and laws (Zeidan \& Jayosi, 2015). The essence of science consists of four elements: science as a process, science as a product, science as attitude and science as an application. The nature of science can be developed, one of them through the lessons of Physics. Physics is a science that deals with the discovery and fundamental understanding of laws that move matter, energy, space and time. Therefore some students are afraid and depressed in understanding the concepts and formulas of physics that are considered very difficult (Sugiarti, 2005). Physics Learning should be taught according to the characteristics of Physics, the use of experimental methods, demonstration and translation of the formula (Subekti \& Ariswan, 2016). In fact, we often found high school students have difficulty in learning Physics so they complain that studying physics is very difficult.

The metacognitive approach is learning that instills awareness of how to design, monitor, and control about something learned, worked on, and focuses on learning activities, helps and guides students' difficulty, and helps students develop selfconcept when they are studying physics (Kramarski, 2008). Uses a metacognitive approach to improve students' critical thinking about problem planning at hand (Pantiwati, 2013). Norma states that: "learning by using metacognitive approaches encourages students to be actively involved in learning".

O'Neil and Brown declare metacognitive as a process in which a person thinks about thinking in order to develop a strategy for solving problems (O'Neil Jr, 
1997). Many researchers receive planning, monitoring and evaluation are the metacognitive skills required in problem solving (Phang, 2009). One learning model that is aligned with the metacognitive approach and can help students in finding concepts and using the process of science is a problem-based learning model. Problem-based learning, determining problems and stages of solving, teachers guide students to do activities by giving a problem and lead to a discussion (Arends, 2008).

Problem-based learning is a process of learning that the overall activities undertaken by students such as investigation planning, observing, analyzing, interpreting data, proposing answers, formulating conclusions and communicating, while educators serve as a motivator that directs and provides guidance either through a complete procedure or question -question questions during the inquiry process (Duron, 2006).

Problem-based learning model (PBL) is a learning model with a real problemsolving focus, a process by which students carry out group work, feedback, discussion. In teacher-based learning acts as a presenter, conducts dialogue, helps and facilitates inquiry. In addition, teachers also provide motivation that can enhance students' intellectual growth. Problem-based learning model (PBL) is given in Physics learning which aims to respond to students' difficulties in the learning process and can encourage students to be able to analyze the shortcomings and difficulties of students in following the learning.

The reciprocal learning model is a new concept in learning that can stimulate students to learn independently, creatively and more actively in following the learning. The reciprocal learning model according to is one of the common alternatives used in the strategy that gives the students the opportunity to analyze the concepts they are reading, take steps in the form of problem solving, compile questions or explain the concepts they learn, and predict them (Palincsar, 1983).

Glaser says critical thinking is a knowledge or skill that can be implemented through discovery. The critical thinking indicator by Edward Glaser is the introduction of problems, interpreting data, presenting data and information, writing conclusions, and recognizing assumptions and values (Fisher, 2009). The ability of critical thinking is very necessary because students become the basic capital to understand various things, such as understanding the concept in the discipline of science (Joyce, 1996). Clearly, learners need critical thinking in academic life, all tasks require critical thinking. Holma shows insufficient for learners to have critical thinking skills, but also need to use these skills effectively. Teachers often ask cognitive questions, questions designed to promote evaluation, synthesis of facts and concepts learned (Magno, 2010).

Ennis defines critical thinking as a reasonable reflective way of thinking or based on focused reasoning, to determine what to believe and do (Ennis, 1996). Critical thinking uses the basis of the thought process to analyze arguments and generate insight into each meaning and interpretation, to develop a logical and logical reasoning pattern, to understand the underlying assumptions and biases of each position, to provide a credible presentation model, concise and convincing. Critical thinking is the intellectually disciplined process of actively and skillfully conceptualizing, applying, analyzing, synthesizing, and/or evaluating information 
gathered from, or generated by, observation, experience, reasoning, or communication, as a guide to belief and action (Sihotang, 2012). Ennis mentions critical thinking indicators as follows: 1) Provide a simple explanation, including focus on questions, analyze arguments, clarify questions; 2) Building basic skills, including assessing the credibility of an information source, making observations and assessing observation reports; 3) Summing up, including making and assessing deductions, making a decision; 4) Provide further explanations, including defining terms and assessing definitions, identifying assumptions; 5) Strategies and tactics, including deciding actions, interacting with others (Ennis, 1996).

Although educators judge a learner who thinks critically about the concept, passion or disposition for critical thinking, but this is not always owned by all learners.

\section{METHOD}

This research was conducted at a high school in Central Java as long as the odd semester 2016/2017. This study uses experimental methods that aim to determine the effect of a variable on other variables. The population is students of grade 11 senior high school. Sampling was done by random cluster sampling, one class as experiment group and one class as a control group. Sampling was done randomly, which then calculated the difference of population mean.

The factorial design of this research is $2 \times 2 \times 2$ with two ways ANOVA statistical analysis that is to know the influence of main factor independent variable in learning model. A moderator variable is critical thinking ability which is categorised into two namely the ability of critical thinking of high and low category to result learn. The equivalence of two sample groups was shown by ttest (Independent Samples Test) with significance level 0,783>0,005 it can be concluded that there is no difference of average achievement value in both classes. The result of the statistical test with t-test obtains one class as experiment class using PBL learning model and control class by using RL model.

Data collection techniques in this study using: (1) documentation techniques to determine the initial ability of students. The earliest capability data obtained are the final semester test (UAS); (2) test techniques to know the learning outcomes of knowledge; (3) Observation technique is used to observe students' attitude and skill during the learning process.

Instruments used in the form of syllabus, RPP, and data retrieval instruments in the form of tests and observation sheets. Instrument form test to measure knowledge learning outcomes. The test form instrument uses multiple choice tests for knowledge. The observation sheet is used to measure the learning outcomes of attitudes and skills in the learning process.

Experts performed the instrument validation test before being tested, including lecturers and education practitioners. After testing the instrument of cognitive learning outcomes, validity, reliability, difficulty and differentiation tests were tested using QUESS software. The data normality test was tested using Kolmogorov-Smirnov, homogeneity test using Bartlett test. The hypothesis of this 
study was tested using ANOVA with the SPSS 18 software. Based on the normality test obtained a significant level of 0.200 for experiment and 0.128 for $\mathrm{s}$ control greater than 0.05 . Then the data of achievement/value of both classes is normal.

\section{RESULT}

Student learning result data is obtained from student test result of static fluid material given after treatment. Data on student learning outcomes are presented in Table 1, for the overall data of the research class. The following learning result data presented in Table 1.

Table 1 Data Description of Student Learning Results $P B L$ $R L$

\begin{tabular}{lcccccc} 
& \multicolumn{3}{c}{$P B L$} & & \multicolumn{3}{c}{$R L$} \\
\cline { 2 - 7 } & Cognitive & Psychomotor & Affective & Cognitive & Psychomotor & Affective \\
\hline $\begin{array}{l}\text { Amount } \\
\text { of data }\end{array}$ & 30 & & & 30 & & \\
\hline Mean & 79,23 & 80,33 & 82,90 & 78,10 & 79,37 & 81,33 \\
\hline SD & 5,685 & 5.707 & 5.540 & 6,150 & 6,054 & 6,140 \\
\hline Max & 92 & 93 & 94 & 91 & 91 & 94 \\
\hline Min & 68 & 69 & 69 & 66 & 67 & 71
\end{tabular}

Table 1. is a description of student learning result data in both experiment class. Based on Table 1., the highest cognitive score of students in PBL class was 92, and RL class was 91. The lowest score in PBL class was 68 higher than the lowest in the RL class of 61.5. The average learning outcomes in the PBL class were 79.51 and the average learning outcome in the RL class was 78.66.

Table 1. also shows that the learning outcomes of students in the PBL class are higher than the RL class. The difference between the learning result between the two classes is 0.84 . The highest score between the two classes has a difference of 2.5 , the highest grade of the RL class is higher than the highest grade of RL. The lowest grade of RL is lower than the lowest grade of PBL ie 6.5.

Data of students' critical thinking ability was obtained from the test with essay test instrument consisting of 10 questions. The students' critical thinking skills are categorized into two, namely high and low. Students are categorized as having high critical thinking skills (KBKT) if the critical thinking skill score is greater than or equal to the mean score of all samples. Students are categorized as having low critical thinking skills if the critical thinking skill score is below the average score of all samples. Data on students' critical thinking ability for high ability category is presented in Table 2.

Table 2 Data Description Student's critical thinking ability

\begin{tabular}{|c|c|c|c|c|c|c|}
\hline \multirow{2}{*}{ Learning } & \multirow{2}{*}{$\mathrm{N}$} & \multicolumn{2}{|c|}{ Mean } & \multicolumn{2}{|c|}{ Student amount } & \multirow{2}{*}{$\begin{array}{l}\text { Cut } \\
\text { off }\end{array}$} \\
\hline & & high & low & high & low & \\
\hline PBL & 30 & 83,47 & 74,93 & 15 & 15 & \multirow{2}{*}{78,72} \\
\hline $\mathrm{RL}$ & 30 & 84,06 & 75,05 & 10 & 20 & \\
\hline
\end{tabular}

The students' critical thinking skills in Table 2. are grouped into high and low average criteria. The total average is accumulated from both classes. The grouping of high and low critical thinking skills categories is based on a mean total value of 
78.72, so this value is used as a cut off or average value limit. If the student has an average score of more than the cut off value, then students' critical thinking skills are categorized as high. If the student has an average score of less than 78.72 , then students' critical thinking skills are categorized as low.

The mean value of high critical thinking skills for the PBL and RL classes based on Table 2 has a difference of 1.2. The average value of high critical thinking skills of the RL class is higher than the mean value of the PBL class. However, the number of students who have high critical thinking skills for the PBL class is more than the RL class. The mean value of low critical thinking skills for the PBL and RL classes based on Table 2. has a difference of 0.12 . The average value of critical thinking skills of low-grade RL is lower than the mean grade of PBL. In addition, the number of students who have low critical thinking skills for the PBL class is less than the RL class. Based on the prerequisite test of the analysis that has been done, it can be concluded that the random sample of observational data comes from the normally distributed and homogeneous populations. The conclusion indicates that the prerequisite analysis test for ANOVA test has been fulfilled, thus hypothesis test analysis with ANOVA technique can be continued. Anava assay was performed using univariate ANOVA univariate with SPSS 18, with significance level of 5\%. The hypothesis test results are summarized in Table 3.

Table 3 Summary of Hypothesis Test Results

\begin{tabular}{lccc}
\hline \multicolumn{1}{c}{$\begin{array}{c}\text { Hypothesis } \\
\text { testing }\end{array}$} & Sig. & conclusion Sig Value. & Decision \\
\hline Learning & 0,000 & $0,00<0,05$ & $\mathrm{H}_{0}$ rejected \\
\hline $\begin{array}{l}\text { Critical } \\
\text { thinking ability }\end{array}$ & 0,010 & $0,00<0,05$ & $\mathrm{H}_{0}$ rejected \\
\hline $\begin{array}{l}\text { Learning } \\
\text { method }\end{array}$ & 0,320 & $0,320>0,05$ & $\mathrm{H}_{0}$ accepted \\
$\begin{array}{l}\text { Critical } \\
\text { thinking ability }\end{array}$ & & & \\
\hline
\end{tabular}

Based on the data in Table 3, it can be concluded about the hypothesis test as follows:

Effect of learning model on student learning outcomes. Testing this hypothesis aims to determine differences in learning outcomes between students who get PBL learning model as an experimental class and RL learning model as a control class. The results of data analysis obtained significance value 0.000 less than 0.05 , and the result of the analysis is that there are differences of learning outcomes between students who are given Physics model of PBL learning using RL model.

The results of this study are in accordance with the research of Erina \& Kuswanto (2015) which shows that there is significant influence of PBL learning model to improve students' learning outcomes in Physics subject and in line with Iswandari research, et al. (2013) that PBL has a significant effect on science process skills and students' learning outcomes in biology lessons.

Nurhidayati's research, et al. (2015) also shows that the PBL method can increase the activity and learning outcomes of students with a very high percentage. 
Students who received learning models PBL obtain higher learning outcomes on aspects of knowledge compared with students who get learning model RL. The average of learning outcomes in PBL class is 79,51, while the mean of learning result in RL class is 78,66.

Differences in learning outcomes based on students' critical thinking skills. Testing this hypothesis aims to determine differences in learning outcomes between students who have high critical thinking skills and students who have low critical thinking skills. The results of data analysis obtained significance value $0.000<0.05$, then the decision test $\mathrm{H} 0 \mathrm{~A}$ rejected and $\mathrm{H} 1 \mathrm{~A}$ accepted. The result of the analysis is there are differences of learning outcomes between students who have high and low critical thinking ability. High critical thinking ability and low critical thinking ability are categorized based on the cut-off value of 78.72 .

The mean value of high critical thinking ability in the experimental class was 83.47, lower than the control class of 84.60. There is a difference of 0.39 . However, the number of students who have high critical thinking skills in the experimental class is more than the control class. In the experimental class, the number of students who can think critically high as many as fifteen students, while the control class as many as ten students.

The average value of low critical thinking ability in the experimental class is 74.93 , higher than the control class of 75.05. The number of students who have low critical thinking skills in the control class is also more than in the experimental class. In the class of dick, the number of students who have low critical thinking ability as many as twenty students, while in the experimental class as many as fifteen students.

These results are in accordance with research conducted by Sugiyanto (2009), namely the ability to think critically contribute to student academic achievement in a positive and significant. Research conducted by Sukimarwati, et al. (2013) also states that the ability to think critically affect the achievement of students and in line with research Irawan Wiratama (2014) which shows that there are differences in student learning outcomes that have the ability to think critically high and low.

The interaction between learning model with students' critical thinking ability. Testing this hypothesis aims to determine the interaction between PBL and RL learning models with students' critical thinking skills. Based on the result of the test decision concluded that there is no interaction between PBL and RL learning model with students' critical thinking ability. This is influenced by several factors.

First, the learning outcomes of knowledge between learning models and critical thinking skills are independent and unrelated. Students with high or low critical thinking skills do not provide interaction to the learning model. Students who have high critical thinking skills if treated with any model will have good learning outcomes. Conversely, students who have low critical thinking skills will have less learning results if treated with any model.

Secondly, the learning outcomes of interaction between learning model and critical thinking ability do not give significant effect because students who have 
the ability of high and low critical thinking ability follow the learning well from beginning to end of the learning process.

Third, the students' learning outcomes have a natural reaction in following the learning activities to prepare the presentation, prepare the tools and materials in the lab, and pay attention to the practicum performed. Students with high critical and low critical thinking both respond well. So, it can be concluded that there is no interaction between the learning model with the ability to think critically about the learning outcomes aspects of knowledge, attitude, and skills. Students who have high and low critical thinking skills will both be able to follow the learning well

\section{CONCLUSION}

The results of this study can be concluded: 1) there are differences in learning outcomes between students who were given learning Physics PBL model with given learning using the RL model. The PBL learning model provides better learning outcomes than the RL learning model. 2) there are differences in learning outcomes between students who have high and low critical thinking skills. Students who have high critical thinking skills get good learning outcomes as well when compared to students who have low critical thinking skills. 3) there is no interaction between PBL and RL learning model with students' critical thinking ability. Learning models and critical thinking skills are different things so that if given a different learning model, students who have high critical thinking skills will get better learning outcomes than students who have low critical thinking skills.

\section{REFERENCES}

Arends, R.I. (2008). Learning to Teach. Belajar untuk Mengajar. Edisi Dua.(Penerjemah: Helly Prayitno Soetjipto dan Sri Mulyantini Soetjipto). Yogyakarta: Pustaka Pelajar.

Badger, R., \& White, G. (2000). A process genre approach to teaching writing. ELT Journal, 54 (2), 153-160.

Duron, R; Limbach, B; Waugh, W. (2006). International Journal of Teaching and Learning in Higher Education, 17 ( 2), 160-166.

Ennis.(1996). Critical Thinking. New York: Prentice Hall, upper saddle river

Fisher, Ale. (2009). Berpikir Kritis Sebuah Pengantar. Erlangga

Joyce, Bruce dan Marsha Weil. (1996). Models of Learning. Mars: Allyn dan Bacon.

Kramarski, B. dan Zoldan, S. (2008). Using Errors as Springboard for Enhancing Mathematical Reasoning with Three Metacognitive Approaches. Proquest Journal. 
Magno, C. (2010). The Role of Metacognitive Skills in Developing Critical Thinking. Metacognitive Learning. 5, 137-156. Springer Science Business Media.

O’Neil Jr, H.F. dan Brown, R.S. (1997). Differential Effects of Question Formats inMath Assessment on Metacognition and Affect. Los Angeles: CRESSTCSE University of California.

Palincsar, A.S., \& Brown, A.L. (1983). Reciprocal teaching of comprehension: Fostering and comprehension-monitoring activities. Cognition and Instruction, 1(2), 117-175. Retrieved May 29, 2008, from Google Scholar.

Pantiwati, Y. (2013). Authentic Assessment for Improving Cognitive Skill, Critical- Creative Thinking and Meta-Cognitive Awareness. Journal of Education and Practice. 4(14). [Online]. Accessed through www.iiste.org

Sihotang, Kasdin, (2012). Critical Thinking. Jakarta: PT Pustaka Sinar Harapan. 
